\title{
Synthesis of Ureidosuccinic Acid with Soluble Enzymes from Liver Mitochondria and Escherichia coli*
}

\author{
PETER REICHARD and GUNNAR HANSHOFF
}

Department of Biochemistry, Karolinska Institutet, Stockholm, Sweden

\begin{abstract}
An extract from rat liver mitochondria catalyzed the enzymatic formation of ureidosuccinic acid from aspartic acid, $\mathrm{NH}_{3}$ and $\mathrm{CO}_{2}$ in the presence of acetylglutamate, $\mathbf{M g}^{++}, \mathbf{A T P}$ and an ATP regenerating system. It was shown that the reaction proceeded in two enzymatic steps. The first involved the formation of compound $\mathbf{X}$ from acetylglutamate, $\mathrm{NH}_{3}, \mathrm{CO}_{2}$ and $\mathrm{ATP}$ in the presence of $\mathrm{Mg}^{++}$. In the second step compound $\mathrm{X}$ was condensed with aspartate to form ureidosuccinate.

The enzyme catalyzing the second step was also present in rat spleen, kidney and heart and in an extract of $E$. coli.

The enzyme from $E$. coli was purified about tenfold and found to catalyze the following reaction:

L-aspartate + compound $\mathbf{X} \rightarrow$ L-ureidosuccinate (+ acetylglutamate + phosphate).
\end{abstract}

The enzymatic synthesis of ureidosuccinic acid (USA **) has been de1 monstrated with isolated mitochondria from rat liver. 1 It was found that

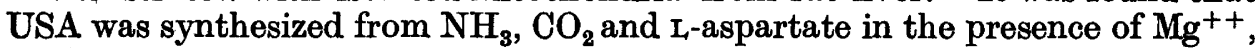
ATP and carbamyglutamate under conditions where ATP was regenerated by oxidation of glutamate or succinate.

The requirement of a substituted glutamate derivative suggested a similarity between USA synthesis and the enzymatic synthesis of citrulline, which is also localized in rat liver mitochondria. The work of Grisolia and Cohen (see e.g. Grisolia ${ }^{3}$ ) has demonstrated that the enzymatic synthesis of citrulline requires at least two steps. The first involves an "activation" of $\mathrm{CO}_{2}$ and $\mathrm{NH}_{3}$ with a substituted glutamate derivative (e.g. carbamylglutamate or acetylglutamate) and ATP in the presence of $\mathrm{Mg}^{++}$to form an unstable "compound X" whose exact structure has not yet been elucidated:

* A preliminary report of part of this work was given at a meeting of the Swedish Biochemical Society (Acta Chem. Scand. 8 (1954) 1102).

** The following abbrevations are used in this paper: USA, ureidosuccinic acid; ATP, adenosine triphosphate; PGA, 3-phosphoglyceric acid; PCA, perchloric acid; MP, muscle protein fraction, prepared according to Ratner and Pappas ${ }^{2}$.

Acta Chem. Scand.9 (1955) No. 3 


$$
\mathrm{NH}_{3}+\mathrm{CO}_{2}+\mathrm{ATP}+\text { acetylglutamate } \rightarrow \text { compound } \mathrm{X}+\mathrm{ADP}
$$

In the second reaction citrulline is formed by condensation of compound $X$ with ornithine:

$$
\text { Compound } \mathbf{X}+\text { ornithine } \rightarrow \text { citrulline }+ \text { acetylglutamate }+\mathbf{P}_{\mathbf{i}}
$$

USA synthesis also involves a fixation of ammonia and carbon dioxide on an amino group which is carried out with the aid of carbamyl- or acetylglutamate and ATP ${ }^{1}$. It seemed rather probable, therefore, that reaction (1) was the first step in USA synthesis also, followed in sequence by the final reaction:

Compound $\mathbf{X}+\mathrm{L}_{\text {-aspartate }} \rightarrow$ L-ureidosuccinate + acetylglutamate $+\mathbf{P}_{\mathbf{i}}$

The present paper describes evidence obtained for reactions $(1)+(3)$ in extracts from rat liver mitochondria. Reaction (3) has furthermore been studied with a partially purified enzyme from $E$. coli.

After the completion of this work Lowenstein and Cohen ${ }^{4}$ have briefly described the formation of labelod USA from ${ }^{14} \mathrm{C}$-compound $X$ in rat liver supernatant.

\section{MATERIALS AND METHODS}

I-Acetylghutamic acid was synthesized eccording to Karrer et al. ${ }^{5}$, D, $\mathrm{L}$-ureidosuccinic acid according to Nyc and Mitchell '. ATP and $P G A$. were purchased as barium salts from Sigma company. The sodium salts were prepared as described earlier for ATP ${ }^{1}$.

I-Aspartic acid-15 $\mathrm{N}$ and $\mathrm{I}_{\text {-aspartic }}$ aeid-2,3-14 $C$ have been synthesized earlier ${ }^{i}$.

Acetone powder of rat liver residue and enzyme $B$ (obtained by alcohol fractionation of the acetone powder extract) were prepared as described by Grisolia and Cohen ${ }^{8}$.

Compound $X$ was prepared enzymatically and purified according to an unpublished method of Grisolia *. It was found that optimal time conditions for obtaining compound $\mathrm{X}$ synthesis had to be determined for each preparation of enzyme B. As already demonstrated by Grisolia and Cohen the amount of compound $X$ formed reached a maximum after some time and then rapidly decreased. Increasing enzyme concentration produced compound $X$ in maximal yields of 40-50\% (based on acetylglutamate). Further increases in enzyme concentration served only to produce a more rapid formation of about the same amount of compound X. These interrelationships are demonstrated by Fig. 1.

For each new enzyme preparation a time curve of optimal compound $\mathbf{X}$ synthesis was determined with an enzyme concentration of $10 \mathrm{mg} / \mathrm{ml}$. The same enzyme preparation gave then very reproducible results.

Purification of compound $X$ was carried to the "20\% pure" stage according to Grisolia's description with isolation as the calcium salt. According to the enzymatic assay (formation of citrulline with heat denatured enzyme $B$ and ornithine ${ }^{8}$ ) different preparations contained between 16:5-21\% compound X. A nitrogen analysis in one case showed that $62 \%$ of the nitrogen in the calcium precipitate corresponded to com. pound $\mathrm{X}$. When ${ }^{15} \mathrm{NH}_{4} \mathrm{Cl}$ was used for the preparation of compound $\mathrm{X}$, isotope analysis of the "20 \% pure" precipitate showed that $42 \%$ of all nitrogen originated from the iso: topic ammonia. Pure compound $\mathrm{X}$ would give a value of $50 \%$, since only one out of two nitrogen atoms stems from ammonia. The data thus indicate that a greater part of the impurities in the " $20 \%$ pure". precipitate do not contain nitrogen. Light ebsorption.meas: urements of an extract of compound $X$ showed only negligable absorption at 2600 . $A$ (corresponding to less than one molecule of adenine derivative per 100 molecules of compound $\mathrm{X}$ ).

* We wish to express our great appreciation to Dr. Grisolia who gave us the details of the method for preparation of compound $\mathbf{X}$ before publication.

Acta Chem. Scund 9 (1955) No. 3 
Fig. 1. Synthesis of compound X. Each vessel contained per ml: 2 umole $A T P$, 25 umole $P G A, 20$ umole $M g S O_{4}, 10$ umole acetylglutamate, 15 umole $\mathrm{NaHCO_{3 }}, 20 \mu$ mole $\mathrm{NH}_{4} \mathrm{Cl}, 2 \mathrm{mg} \mathrm{MP}$. $\mathrm{pH}=7.3 . \mathrm{O}=15 \mathrm{mg}$ enzyme $B, O=10 \mathrm{mg}$ enzyme $B$. The values for the formation of compound $X$ are given for $1 \mathrm{ml}$.

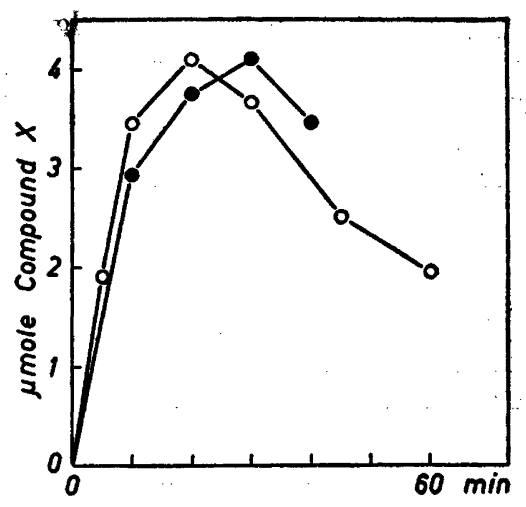

Quantitative analysis for compound $\mathbf{X}$ was carried out with heat treated enzyme $\mathbf{B}^{8}$. Analysis for citrulline was made according to Koritz and Cohen ${ }^{9}$.

Determination of ureidosuccinate. The experiments were carried out with isotopic substrates. In the study of the liver enzyme ${ }^{15} \mathrm{NH}_{4} \mathrm{Cl}$ and $\mathrm{L}_{\mathrm{-}}$-aspartate- ${ }^{15} \mathrm{~N}$ were used. The amount of USA formed was then determined by the isotope dilution method as described

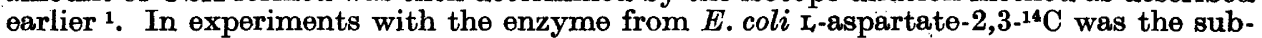
strate together with nonlabeled ammonia and $\mathrm{CO}_{2}$, or compound $\mathrm{X}$. At the end of each experiment carrier nonlabeled USA (usually $200 \mu \mathrm{moles}$ ) was added and the amount of enzymatically formed USA was calculated from the radioactivity in the reisolated substance. Radioactivity determinations were carried out on infinitely thin samples in a windowless gas flow counter. Since the aspartic acid used as substrate contained 12000 ct/min./ $\mu$ mole (infinite thin sample) the amount of enzymatically formed USA could be calculated according to:

$$
\mu \text { moles USA formed }=200 \cdot a / 12000=a / 60
$$

where $a=\mathrm{ct} / \mathrm{min} / \mu \mathrm{mole}$ in the reisolated USA.

\section{RESULTS}

USA synthesis in mitochondrial extracts

Preparation of enzyme. Rat or rabbit liver mitochondria were prepared as described earlier ${ }^{1}$ by differential centrifugation according to the principles worked out by Schneider and Hogeboom ${ }^{10}$. The enzymes synthesizing USA could be obtained in solution after rupture of the mitochondrial membrane. This could be done by suspension of the washed mitochondria in distilled water or by sonic vibration. The latter treatment, however, rapidly inactivated the enzymes, while following osmotic rupture more than $50 \%$ of the enzymatic activity remained in the sediment after centrifugation of the lysed mitochondria. The best yield of soluble enzymes was obtained by a quick freezing and thawing of a mitochondrial suspension in $0.1 \mathrm{M} \mathrm{NaHCO}_{3}(10-20 \mathrm{ml}$ solution per $10 \mathrm{~g}$ of liver). When the resulting suspension of broken mitochondria was centrifuged at $20000-100000 \mathrm{~g}$ for 20 minutes at $0^{\circ}$ most of the activity was located in the supernatant. Not quite as good results were obtained using $0.1 M$ potassium phosphate buffer, pH 7.5, or isotonic $\mathrm{KCl}$ as the suspending solution. Freezing in distilled water destroyed most of the activity. Repeated freezing and thawing in bicarbonate also decreased the activity.

Acta Chem. Scand. 9 (1955) No. 3 
Routinely the enzyme was prepared in $0.1 \mathrm{M} \mathrm{NaHCO}_{3}$. The clear supernatant was filtered through cotton wool to remove fat particles and could then be lyophilized and stored as a dry powder in a dessicator at - $10^{\circ}$. Enzymatic activity invariably decreased during storage, although there was considerable variation in the rate of decline of activity with different preparations. More than $50 \%$ of the initial activity was usually retained for 2 weeks.

Most of the experiments were carried out with rat liver mitochondrial extracts, which contained the highest enzymatic acitivities (per amount of nitrogen). Some experiments with rabbit liver mitochondrial preparations were included, although here more variation in activity among preparations was encountered.

Table 1. Requirements for USA synthesis in mitochondrial extract.

\begin{tabular}{|l|c|}
\hline & $\mu$ mole ureidosuccinate formed \\
\cline { 2 - 2 } & \\
complete substrate & $\mathbf{0 . 7 0}$ \\
- aspartate & 0.01 \\
- ammonia. & 0.07 \\
- ATP, PGA, MP & $\mathbf{0 . 0 2}$ \\
- PGA, MP & $\mathbf{0 . 0 0}$ \\
- acetylglutamate & $\mathbf{0 . 1 5}$ \\
\hline
\end{tabular}

Complete substrate: $30 \mu$ mole L-aspartate-15 $\mathrm{N}, 30 \mu$ mole ${ }^{15} \mathrm{NH}_{4} \mathrm{Cl}, 25 \mu$ mole $\mathrm{MgCl}_{2}$ $10 \mu$ mole ATP, $50 \mu$ mole PGA, $15 \mu$ mole acetylglutamate, $100 \mu$ mole phosphate buffer $\mathrm{pH} 7.2,3 \mathrm{mg}$ MP. Volume $=3 \mathrm{ml}$. All acids neutralized with $\mathrm{KOH}$. Incubation for 90 minutes at $37^{\circ}$ with $1 \mathrm{mg}$ enzyme nitrogen.

Overall requirements for USA synthesis. USA was synthesized from the same substrates by the extracts as by the intact mitochondria and also required the presence of acetylglutamate (or carbamylglutamate), $\mathrm{Mg}^{++}$and ATP (Table 1). Acetylglutamate was used throughout the present investigation rather than carbamylglutamate, which had been used with intact mitochondria ${ }^{1}$, since it was found that smaller concentrations of acetylglutamate gave optimal USA synthesis with intact mitochondria. This is in accordance with the results obtained by Grisolia and Cohen 11 on citrulline synthesis.

In the absence of acetylglutamate USA synthesis was reduced from 0.70 $\mu$ mole to $0.04 \mu$ mole under the experimental conditions of Table 1 . The catalytic nature of acetylglutamate requirement in the overall reaction could be demonstrated in an experiment, in which only $0.5 \mu$ mole of acetylglutamate was present in the substrate. During 6 hours incubation $2.1 \mu$ mole of USA was formed. Except for acetylglutamate conditions were as in Table 1. Another $50 \mu$ mole of PGA was added after 3 hours.

In the absence of ATP no USA synthesis was obtained with rat liver mitochondrial extracts and an otherwise complete substrate (Table 1). ATP was broken down during the reaction by ATP-ases in the extract. For optimal synthesis of USA, 3-phospho-glyceric acid and a muscle protein fraction had to 
Fig. 2. Time curve for USA formation in mitochondrial extract. Curve $I=$ overall reaction, curve $I I=$ formation from puri. fied compound $X$.

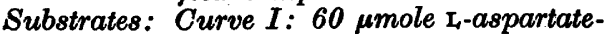

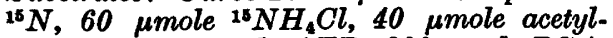

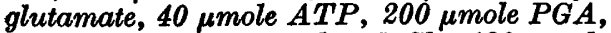
$12 \mathrm{mg} M P$, 100 mole $\mathrm{MgCl}_{\mathrm{g}}, 120$ umole phosphate buffer, $p H$ 7.2. Volume $=12 \mathrm{ml}$. $4.1 \mathrm{mg}$ enzyme nitrogen. Curve II: 25 umole r-aspartate- ${ }^{14} \mathrm{C}, 22$ umole compound $X *$, 500 umole phosphate buffer, $\mathrm{pH}=7.0$. Volume $=15 \mathrm{ml}$. $4.8 \mathrm{mg}$ enzyme nitrogen.

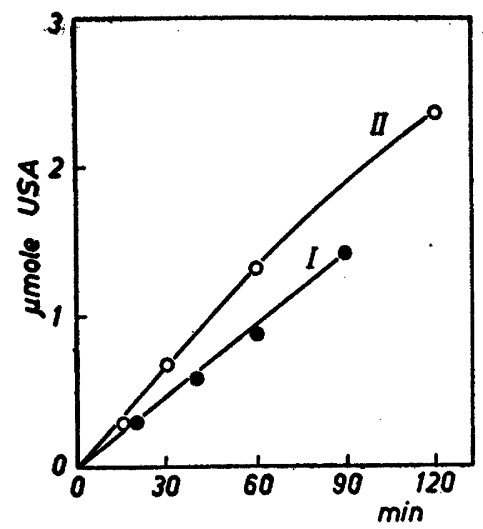

be added in order to regenerate ATP. The same general type of behaviour has been found first by Ratner in arginine synthesis ${ }^{2}$ and also by Grisolia and Cohen ${ }^{8}$ in citrulline synthesis. In both cases the accumulation of ADP formed by ATP breakdown inhibited the reaction. Ratner showed that this difficulty could be overcome by the addition of PGA which in the presence of a suitable ammonium sulfate fraction from a muscle extract regenerates ATP from ADP.

The time curve of the overall reaction is given by Fig. 2, curve I. The influence of enzyme concentration is demonstrated by Fig. 3.

Stepwise synthesis of USA. An extract from acetone powder of liver residue ${ }^{8}$ which showed good activity for citrulline synthesis formed very little USA under the present conditions. The mitochondrial extract, on the other hand, could synthesize either citrulline or USA. This marked difference between the two preparations in the relative ability to synthesize citrulline and USA (summarized in Table 2) demonstrates that at least one enzyme in USA synthesis is different from the enzymes in citrulline synthesis.

Fig. 3. Overall formation of ureidosuccinate with different amounts of enzyme. Substrate as in Table 1. Incubation for $90 \mathrm{~min}$. at $37^{\circ}$.

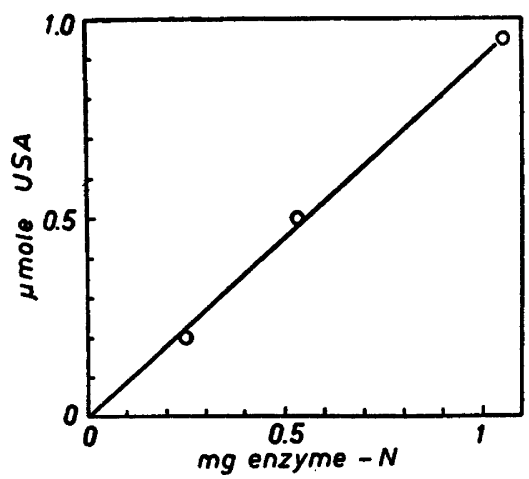

* The finely divided Ca-salt of compound $X$ was extracted for two minutes with ice cold water $(2-8 \mathrm{ml}$ of water/50 $\mathrm{mg} C a$-salt), a slight excess of potassium oxalate ( $M$ solution) was added and the suspension centrifuged in the cold.j. Aliquots of the solution were immediately used for a serie of experiments

Acta Chem. Scand. 9 (1955) No. 3 
Table 2. Non identity of enzym for citrulline and ureidosuccinate synthesis.

\begin{tabular}{|c|c|c|}
\hline & \multicolumn{2}{|c|}{ Synthesized per mg enzyme nitrogen } \\
\cline { 2 - 3 } & $\mu$ mole of citrulline & $\mu$ mole of ureidosuccinate \\
\hline & & \\
Acetone powder extract: & & \\
30 min. incubation & 0.97 & 0.05 \\
90 min. incubation & 1.92 & 0.04 \\
\hline & & \\
Mitochondrial extract: & 1.03 & 0.40 \\
30 min. incubation & 1.03 & 0.89 \\
90 min. incubation & & \\
\hline
\end{tabular}

Substrates as in Table 1 for ureidosuccinate synthesis. In the citrulline experiments $20 \mu$ mole of $\mathrm{NaHCO}_{3}$ was added to esch medium and $20 \mu$ mole ornithine was substituted for I-aspertatio.

Table 3 demonstrates that more than one enzyme is involved in USA synthesis. When the mitochondrial enzyme was heated at $54^{\circ}$ for 3 minutes (pH 7.4) its ability to synthesize USA was almost completely destroyed. This treatment has been shown to inactivate the first step in citrulline synthesis ${ }^{8}$. The combination of this heated mitochondrial enzyme and acetone powder extract, each of which was virtually inactive alone, synthesized USA actively (Table 3). The addition of heated mitochondrial enzyme to a non heat-treated mitochondrial enzyme increased USA formation somewhat. Addition of acetone powder extract did not show this effect.

The results fit the following interpretations: (1) The first step of USA synthesis is present in the acetone powder and is heat labile. (2) The second step is contained in mitochondrial extract and is more heat stable (although a considerable part of the activity is also destroyed by heating at $54^{\circ}$ for 3 minutes). (3) The second step seems to be limiting in the untreated mitochondrial extract, since addition of the heated mitochondrial enzyme increased USA formation, while addition of acetone powder extract had no effect.

Table 3. Involvement of several enzymes in ureidosuccinate synthesis. Substrate and conditions as in Table 1.

\begin{tabular}{|l|l|}
\hline \multicolumn{1}{|c|}{ Enzyme preparation } & $\mu$ mole of ureidosuccinate formed \\
\hline Mitochondrial extract (ME), 1 mg enzyme-N & 1.45 \\
Mitochondrial extract, 3 min. at 54 (MEH) & 0.10 \\
(1.5 mg enzyme-N) & 0.07 \\
Acetone powder extract (AP), 0.5 mg enzyme-N & 1.90 \\
ME + MEH & 1.38 \\
ME + AP & 0.42 \\
\hline
\end{tabular}

Acta Chem. Scand. 9 (1955) No. 3 
Table 4. Stepwise synthesis of ureidosuccinate.

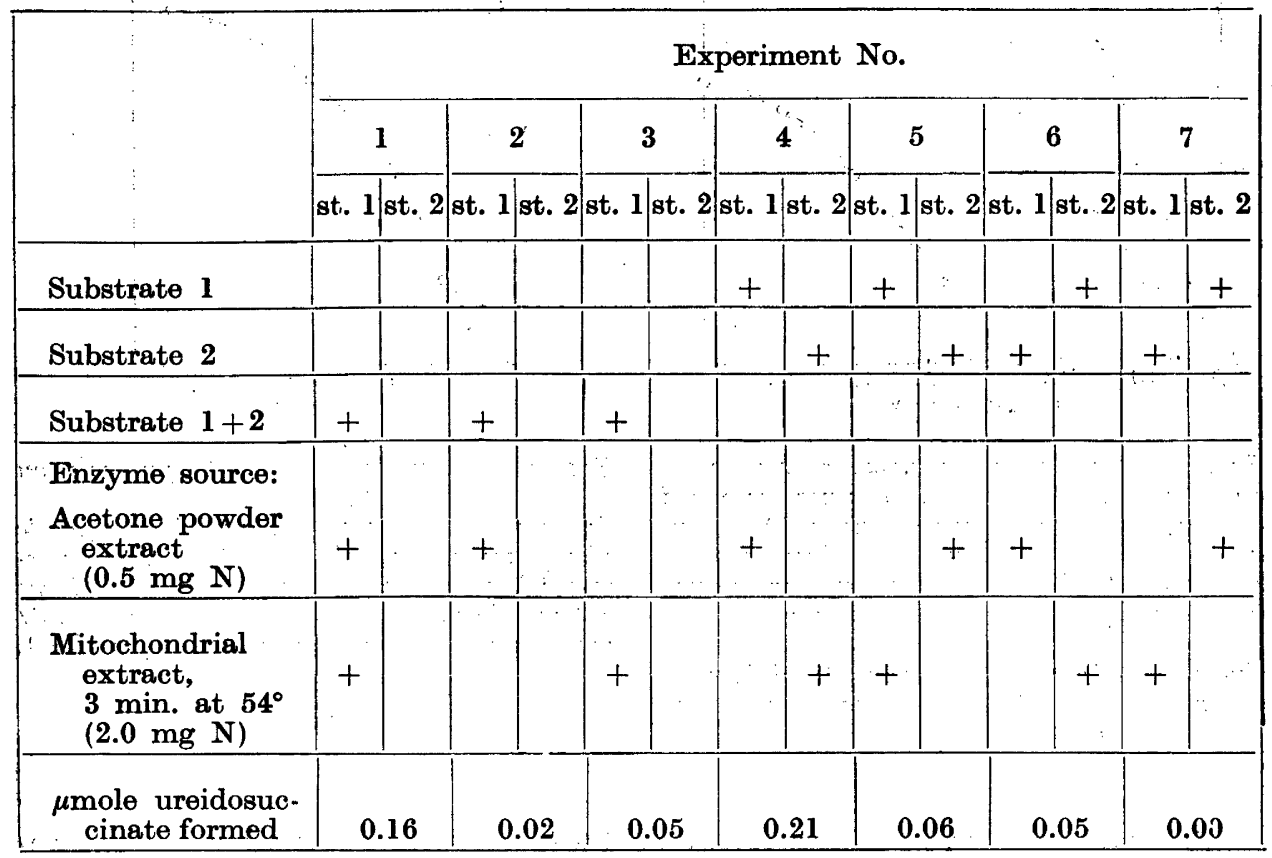

Substrate 1: $30 \mu$ mole ${ }^{15} \mathrm{NH}_{4} \mathrm{Cl}, 20 \mu$ mole $\mathrm{NaHCO}_{3}, 10 \mu$ mole ATP, $50 \mu$ mole PGA, $15 \mu$ mole acetylglutamate, $25 \mu$ mole $^{\mathrm{MgCl}_{2}}, 100 \mu$ mole phosphate buffer, $\mathrm{pH} 7.2,2 \mathrm{mg} \mathrm{MP}$. Volume $=3 \mathrm{ml}$.

Substrate 2: $30 \mu$ mole L-aspartate- ${ }^{15} \mathrm{~N}, 100 \mu$ mole phosphate buffer, $\mathrm{pH}$ 7.2. Volume $=3 \mathrm{ml}$. 60 minutes incubation at $37^{\circ}$ for each step.

A more direct demonstration of this reaction sequence is given by the experiments summarized in Table 4. Experiments $1-3$ demonstrate again that the presence of both the heated mitochondrial enzyme and the acetone powder is required for USA synthesis. In experiments 4-7 the study of USA formation was carried out in stepwise sequence. The substrate was divided into two parts: substrate 1 containing everything necessary for reaction (1), i.e. the formation of compound $\mathrm{X}$; substrate 2 containing only aspartate (and buffer). In the first step an enzyme preparation was incubated with one substrate for 60 minutes at $37^{\circ}$. The reaction was then stopped by addition of $0.5 \mathrm{ml} N$ PCA to the cooled solution. After 5 minutes in an ice bath the solution was neutralized to $\mathrm{pH} 7$ with $\mathrm{N} \mathrm{NaHCO}$. The second step was then studied by the addition of the other enzyme and substrate, and incubation for an additional 60 minutes at $37^{\circ}$. Using the four possible combinations of substrates and enzymes it could be shown that the first step required the enzyme from the acetone powder extract and the substrate necessary for the formation of compound $\mathrm{X}$, while the second step involved the participation of aspartate and the enzyme from the heated mitochondrial extract.

Acta Chem. Scand. 9 (1955) No. 3 


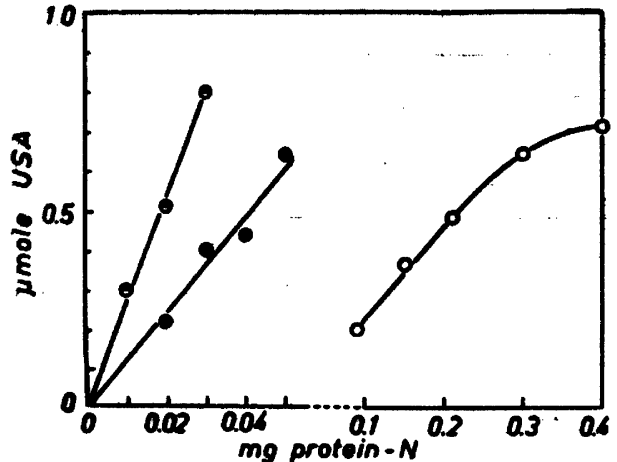

Fig. 4. Formation of ureidosuccinate by enzyme from $\mathbf{E}$. coli. $\mathrm{O}=$ unfractionated extract, $=$ protamine fraction, $\mathrm{O}=$ am moniumsulfate fraction. The abscissa gives the lamount of enzyme nitrogen per experiment for each point. Incubation at $37^{\circ}$, 15 min.

Substrate: 10 umole $\mathrm{L}_{\mathrm{H}}$-aspartate-14 $C, 2.6$ umole compound $X, 100$ umole phosphate buffer, pH 6.5. Volume $1.3 \mathrm{ml}$.

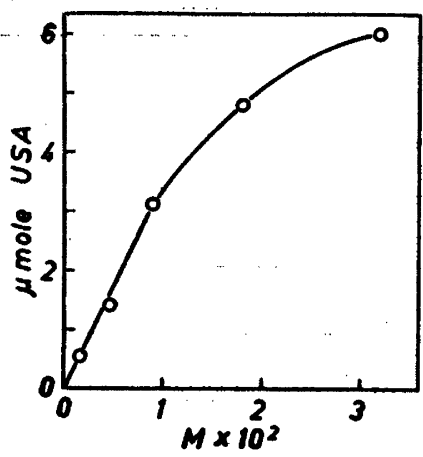

Fig. 5. Dependence of USA synthesis on I-aspartate.

Substrate: 7.7 mole compound $X, 150$ mmole phosphate buffer, $p H=6.5$, and $\mathrm{L}_{\text {-aspar- }}$ tate-1" $C$ as indicated on abscissa. Volume $3.7 \mathrm{ml}$. Incubation 15 min. at $37^{\circ}$ with 0.07 mg enzyme-N (ammonium sulfate fraction).

A direct demonstration of reaction (3) was obtained by incubation of mitochondrial enzyme with aspartic acid and compound $X$. In this experiment L-aspartate-14 $\mathrm{C}$ was used. The resulting time curve of USA formation is shown in curve II of Fig. 2.

Experiments with enzyme from $E$. coli.

Studies of the condensing enzyme from liver which catalyzes reaction (3) were greatly hampered by the instability of the enzyme. The enzyme was also found to be present in rat kidney, spleen and heart, yeast autolysate and an extract of lyophilized $E$. coli. By far the highest activity was observed in the bacterial extract and further investigations were therefore carried out with the enzyme from this source.

Assay system. The bacterial extract showed no ability to synthesize USA from ammonia, bicarbonate and aspartic acid and thus contained little or no enzyme activity for reaction (1). Since the bacterial enzyme formed no compound $\mathbf{X}$, it was not necessary to use purified compound $\mathbf{X}$ for the assay. It was instead prepared in solution by incubation of ammonia, $\mathrm{NaHCO}_{3}$, ATP and acetylglutamate together with "enzyme B" 8, as described in the experimental part. The reaction was stopped by addition of 0.2 volumes of $0.5 M$ PCA to the cooled solution. After centrifugation and neutralization to $\mathrm{pH} 6.5$ with $N \mathrm{KOH}$ an aliquot of the solution containing $2.6 \mu$ mole of compound $\mathrm{X}$ was added to $10 \mu$ mole of aspartate- ${ }^{14} \mathrm{C}$ and $100 \mu$ mole of phosphate buffer $\mathrm{pH} 6.5$. The bacterial enzyme was added and incubation (final volume $1.3 \mathrm{ml}$ ) carried 
out for 15 minutes at $37^{\circ}$. Under these costitions USA formation (in the range $0.2-0.5 \mu$ mole) was proportional to the amount of enzyme added (see Fig. 4).

Quite large amounts of substrate are needed to saturate the enzyme (see below) and the conditions described do not permit maximal USA synthesis. Lack of sufficient substrate did not allow work with substrate-saturated enzymes. When an exact assay of the enzyme activity was desired several experiments at different enzyme concentrations were carried out and satisfactory results were obtained.

Purification of the enzyme. The lyophilized $E$. coli preparation was obtained through the courtesy of Dr. G. Hedén of the Bacteriological Department of the Karolinska Institutet. The cells had been grown on a synthetic liquid medium ${ }^{12}$ for 18 hours. After this time the cells were harvested in a Sharples centrifuge, washed once with $0.9 \% \mathrm{NaCl}$ and lyophilized. At this stage the preparation, when stored in a desiccator in the cold room, retained enzymatic activity for at least one year.

Extraction of the cells was carried out by sonic vibration with glass beads $(0.28 \mathrm{~mm}$ diameter $)$. Five $\mathrm{g}$ of the lyophilized powder was homogenized in $50 \mathrm{ml}$ of $0.1 \mathrm{M} \mathrm{NaHCO}$. $40 \mathrm{ml}$ of glass beads were added and vibration carried out by a "microid flask shaker" (Griffin and Tatlock, Ltd) at room temperature for 90 minutes. The very viscous solution was separated from the glass beads by filtration. The beads were washed with $50 \mathrm{ml}$ of $0.1 M \mathrm{NaHCO}_{3}$. The combined filtrate and washings were centrifuged at $20000 \mathrm{~g}$ at $20^{\circ}$ for 30 minutes. $65 \mathrm{ml}$ of slightly turbid supernatant was obtained.

To the supernatant was added $32.5 \mathrm{ml}$ of a $2 \%$ solution of protamine sulfate (neutralized to $\mathrm{pH} 8$ with $0.5 \mathrm{~N} \mathrm{NaOH}$ ). The resulting stringy precipitate was centrifuged and the supernatant discarded. The precipitate was finely homogenized in $15 \mathrm{ml}$ of $0.1 M$ potassium phosphate buffer, $\mathrm{pH}$ 7. After centrifugation the precipitate was once more extracted in the same way and centrifuged. All operations up to this step were carried out at room temperature.

The combined supernatants $(30 \mathrm{ml})$ were cooled in an ice bath. Solid ammonium sulfate $(6.35 \mathrm{~g})$ was added to bring the solution to $30 \%$ saturation. After standing for 10 minutes the precipitate was centrifuged off and discarded. More ammonium sulfate $(3.1 \mathrm{~g})$ was added to the supernatant and the solution centrifuged after 10 minutes. The resulting precipitate contained most of the enzymatic activity. It was dissolved in $5 \mathrm{ml}$ of $0.1 M$ phosphate buffer; $\mathrm{pH}$ 6.5, and could be stored in the deep freeze. Most experiments were carried out

Table 5. Purification of condensing enzyme from E. coli.

\begin{tabular}{|c|c|c|c|}
\hline & mg protein nitrogen & total units & units $/ \mathrm{mg} \mathrm{N}$ \\
\hline Extract & 259 & 1220 & 4.7 \\
\hline Protamine precipitate & 37 & 870 & 23 \\
\hline $\begin{array}{c}\text { Ammonium sulfate, } \\
30-45 \% \text { sat. }\end{array}$ & 11.5 & 620 & 54 \\
\hline
\end{tabular}




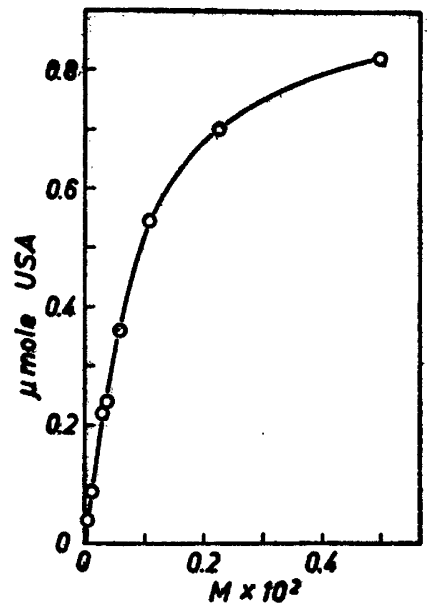

Fig. 6. Dependence of USA synthesis on compound $\boldsymbol{X}$.

Substrate: 5 mmole L-aspartate- ${ }^{14} C, 150$ umole phosphate buffer, $p H$ 6.5, compound $X$ as indicated on absoissa. Volume $3.7 \mathrm{ml}$. In cubation at $37^{\circ}$ for $15 \mathrm{~min}$. with $0.07 \mathrm{mg}$ en: zyme nitrogen (ammonium sulfate fraction).

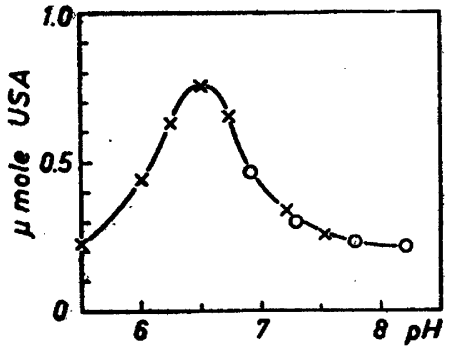

Fig. 7. $p H$ curve of USA synthesis. Substrate: $4.5 \mu$ mole compound $X, 5$ mmole L-aspartate-14 $C, 250$ umole buffer $(X=$ phosphate, $\mathrm{O}=$ glycylglycine). Incubation at $37^{\circ}$ for 15 min. with $0.07 \mathrm{mg}$ enzyme nitrogen. (ammonium sulfate fraction). Volume $3.7 \mathrm{ml}$.

with this fraction. Dialysis of the solution for 18 hours at $+2^{\circ}$ against $0.01 M$ phosphate buffer resulted in the loss of ca $30 \%$ of the activity. The dialyzed solution could be lyophilized without further loss of activity. A summary of the purification procedure is given in Table 5 .

Some properties of the reaction. The dependence of the reaction on the simultaneous presence of $I_{1}$-aspartate and compound $\mathbf{X}$ is demonstrated by Figs. 5 and 6. All experiments subsequently described were carried out with purified compound $X$. Although it was not possible to effect enzyme saturation under the present experimental conditions, the results are sufficient to indicate that high concentrations of compound $X$ and especially aspartate would be necessary for optimal synthesis*. The pH optimum of the reaction was at 6.5. Phosphate was without influence on the reaction (Fig. 7).

$\mathrm{Mg}^{++}, \mathrm{Zn}^{++}, \mathrm{Mn}^{++}, \mathrm{Ca}^{++}$and $\mathrm{Fe}^{++}$did not stimulate USA formation by lyophilized, dialyzed bacterial enzyme under the following experimental conditions. In each experiment $1.0 \mathrm{mg}$ of enzyme was incubated with $5 \mu$ mole of L-aspartate- ${ }^{14} \mathrm{C}$ and $4 \mu$ mole compound $\mathrm{X}$ in a final volume of $2.8 \mathrm{ml}$, pH 7.2. In the presence of $10 \mu$ mole of either $\mathrm{MnCl}_{2}, \mathrm{ZnCl}_{2}, \mathrm{CaCl}_{2}$, or $\mathrm{FeSO}_{4}$ the following amounts of USA (in $\mu$ moles) were synthesized during 30 minutes at $37^{\circ}$ : $1.11 ; 1.00 ; 1.09 ; 1.09$. In the control experiment without addition of divalent ions, $1.01 \mu$ mole of USA was formed. In another similar experiment $0.81 \mu \mathrm{mole}$

* The experiments were complicated by the fact that at high concentrations of the reactants a non-enzymatic formation of USA took place. This was negligible under the conditions for enzyme assay. However, under the conditions of Fig. 5 an increasing part of the USA synthesis observed at aspartate concentrations above $0.5 \times 10^{-2} M$ was non-enzymatic. 
Fig. 8. Time curve and stoichiometry of $U S A$ formation.

Substrate: 25 mmole L-aspartate_14 $C, 22 \mu$ mole compound $X \cdot{ }^{16} \mathrm{~N}, 1250$ mole glycyl-glycine. buffer, $p H$ 7.0. $\times=$ values calc. from ${ }^{14} \mathrm{C}$; $\mathrm{O}=$ values calc. from ${ }^{15} \mathrm{~N}$. Volyme $=15$ ml. For further explanation see text.

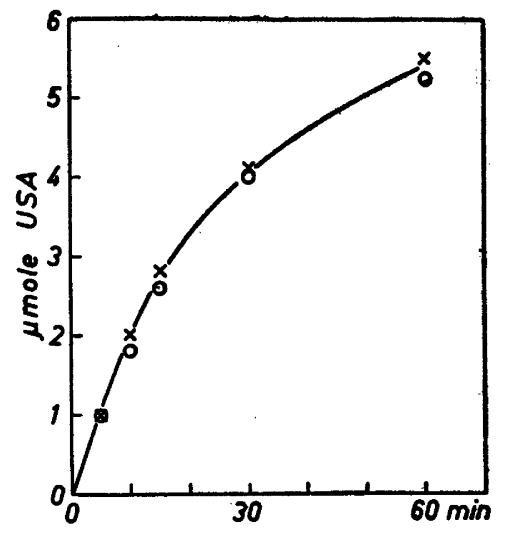

of USA was formed in the presence of $30 \mu$ mole of $\mathrm{MgSO}_{4}$, while $0.85 \mu$ mole was formed in the control.

Stoichiometry of the reaction. The formation of one molecule of USA per one molecule of aspartate and compound $X$ each was demonstrated by the simultaneous use of ${ }^{15} \mathrm{~N}$-labeled compound $\mathrm{X}$ and $\mathrm{L}_{-}$-aspartate- ${ }^{14} \mathrm{C}$ in one experiment. The USA formed stoichiometrically under these experimental conditions should be doubly labeled according to:<smiles>[R]C([NH3+])=O</smiles>

Compound $\mathrm{X}$ was enzymatically synthesized from ${ }^{15} \mathrm{NH}_{4} \mathrm{Cl}\left(32 \%\right.$ excess $\left.{ }^{15} \mathrm{~N}\right)$. The carbamino group of USA therefore contained the same excess of ${ }^{15} \mathrm{~N}$. The succinate moiety of USA contained the same specific activity of ${ }^{14} \mathrm{C}$ as the precursor aspartate. The experiment summarized in Fig. 8 demonstrates the stoichiometric relation. The figure represents a time curve of USA formation. At each time point the amount USA formed was calculated independently from both the ${ }^{15} \mathrm{~N}$ and the ${ }^{14} \mathrm{C}$, respectively, of the reisolated USA. Within experimental error identical values were obtained for each time point.

\section{DISCUSSION}

The experiments described here demonstrate the occurrence in rat organs and $E$. coli of an enzymatic reaction by which ureidosuccinic acid, an intermediate in pyrimidine biogenesis, is formed from aspartic acid and compound $\mathrm{X}$. Compound $\mathrm{X}$ has earlier been described as an intermediate in citrulline synthesis by Grisolia and Cohen ${ }^{8}$. The formation of compound $\mathrm{X}$ from $\mathrm{CO}_{2}$,

Acta. Chem. Scand. 9 (1955) No. 3 
$\mathrm{NH}_{3}$, ATP and a substituted glutamate derivative seems therefore to represent one common step for both citrulline and USA biosynthesis. It is interesting that we were not able to demonstrate the occurrence of this enzymatic reaction in the bacterial extract. The possibility exists that the enzyme responsible for compound $\mathrm{X}$ formation had been destroyed during the preparation of the extract. On the other hand it was not possible to demonstrate this reaction in homogenates from most rat organs, which contained the enzyme forming USA from compound $X$. In the rat, with the exception of liver, only kidney preparations were found to form compound $X$, and here only minimal synthesis was obtained.

It seems unlikely that liver and possibly kidney are the only mammalian organs capable of synthesizing pyrimidines. The widespread existence of the enzyme capable of forming USA from compound $\mathrm{X}$ and aspartate also argues against this. The possibility arises, therefore, that compound $\mathrm{X}$ is synthesized by another mechanism than reaction (1). An example for such a reaction is the recently demonstrated conversion of citrulline-ureido-14 $\mathrm{C}$ to labeled USA, which probably proceeds via compound $\mathrm{X}$ as an intermediate ${ }^{13}$.

\section{REFERENCES}

1. Reichard, P. Acta Chem. Scand. 8 (1954) 795.

2. Ratner, S. and Pappas, A. J. Biol. Chem. 179 (1949) 1183.

3. Grisolia, S. in Mc Elroy, W. D. and Glass, B. Phosphorus Metabolism 1 (1951) 619.

4. Lowenstein, J. M. and Cohen, P. P. J. Am. Chem. Soc. 76 (1954) 5571.

5. Karrer, P., Escher, K. and Widmer, R. Helv. Chem. Acta 9 (1926) 301.

6. Nyc, J. F. and Mitchell, H. K. J. Am. Chem. Soc: 69 (1947) 1382.

7. Reichard, P. and Lagerkvist, U. Acta Chem. Scand. 7 (1953) 1207.

8. Grisolia, S. and Cohen, P. P. J. Biol. Chem. 198 (1952) 561.

9. Koritz, S. B. and Cohen, P. P. J. Biol. Chem. 209 (1954) 145.

10. Schneider, W. C. and Hogeboom, G. H. J. Biol. Chem. 183 (1950) 123.

11. Grisolia, S. and Cohen, P. P. J. Biol. Chem. 204 (1953) 753.

12. Hedén, C. G. Acta Pathol. Microbiol. Scand. Suppl. 88 (1951) 19.

13. Reichard, P. and Smith, L. H., Jr. Acta Chem. Scand. 9 (1955) 194.

Received January 4, 1955. 